\title{
Applying Enterprise: Active Learning Environments for Business Higher National Diploma Students
}

Heather Bell \& Robin Bell

(r.bell@worc.ac.uk)

Journal of Further and Higher Education (2018), Vol. 42, No. 5, pp. 649-661.

http://dx.doi.org/10.1080/0309877X.2017.1302567

\begin{abstract}
This article details an approach to teaching entrepreneurship to Higher National Diploma (HND) students that combines lecture-based and experiential learning processes to increase student learning, comprehension, and entrepreneurial skills. A UK university redesigned an entrepreneurship course to have students design and implement business plans for a pop-up shop and an event in the local community, while working closely with instructors and outside stakeholders. The lectures used in the lessons were designed to complement the enterprise activities and be immediately applied in group work settings. Data were collected from student reflections and analyzed against instructor reflections to highlight both the success and challenges of this approach, as well as any areas of dissonance between student and instructor observations. While the benefits of active and experiential learning processes are highlighted in the literature, this article examines these teaching methods specifically in a HND context, an area in which research on the benefits of these teaching methods for developing entrepreneurial students and for developing students prepared for undergraduate education has been limited.
\end{abstract}

\section{Keywords:}

Active learning; experiential learning; entrepreneurialism; reflection; Higher National Diploma 


\section{Introduction}

As universities and business schools increase their focus on entrepreneurship education, it is often argued that students studying entrepreneurship are not a homogenous group (DuvalCouetil, Gotch and Yi 2014) and that teaching entrepreneurship requires a non-traditional learning environment (Gibb 2002; Jones and English 2004) that focuses on action-oriented teaching methods, experiential learning, problem solving, and completing projects in peer groups (Arvanites et al. 2006; Jones and Iredale 2010). The entrepreneurial process requires specific skills to recognize opportunities, embrace and leverage risks, and create new ventures, processes, and techniques (Jack and Anderson 1999). Zahra and Welter $(2008$, p.188) have argued that 'whilst lecture-based education has its place in the curriculum, the training of future entrepreneurs should also include interactive and action orientated methods.'

Many entrepreneurship educators have accordingly adopted approaches based on Kolb's (1984) experiential learning cycle. Educators have argued for a variety of experiential approaches (e.g. Cornell, Johnson and Schwartz 2013; Chang, Benamraoui and Rieple 2014; Sherman, Sebora and Digman 2008; Reid, Brown and Tabibzadeh 2012; Soloman 2008; Bevan and Kipka 2012; Hynes and Richardson 2007). The most commonly adopted experiential learning formats in business schools include team-building exercises, simulations, guest speakers and internships (Bevan and Kipka 2012).

To determine whether a student is 'entrepreneurial', different approaches have been taken to account for the lack of work experience, entrepreneurial or otherwise, in students, thus making approaches examining actions (building on McClelland et al. 1953) inappropriate. One approach that has been widely used is an attitudinal approach. An entrepreneurial attitude is often defined by the relationship between a number of attitudes or traits that have been found in research to lead to entrepreneurial intention and/or action, based on Ajzen's (1985) theory of planned behavior, which has been applied widely to understand entrepreneurial intention of students (e.g. Fayolle and Gailly 2015; Gird and Bagraim 2008; and Van Gelderen et al. 2008). Individuals with entrepreneurial attitudes have been shown to be able to identify opportunities, 
prepare for the market, present their abilities, and take action to make things happen (Davis, Morris and Allen 1991; Smith, Collins and Hannon 2006). Traits often associated with entrepreneurial intention include a preference for innovation, self-efficacy, non-conformity, a proactive disposition, an internal locus of control, and achievement motivation (Florin, Karri and Rossiter 2007).

Building on this rationale, a new curriculum for a HND entrepreneurship module was developed that combined lectures with hands-on creation of entrepreneurial ventures, including running a 'pop-up shop', an intentionally temporary retail space used to promote a concept or product (Niehm et al. 2007) and designing a themed event that was implemented in the surrounding community. It offered students the chance to understand abstract and applied entrepreneurial concepts by engaging in real-world experiences, reflections, conceptualizing, and experimenting, in line with Kolb's experiential learning cycle. The applied activities increased in length, complexity, and potential profitability throughout the module, providing a scaffolded approach. Students were guided through reflective practices throughout the module. Unlike many courses that use simulations, the module placed students into real business settings and allowed students to make decisions and take risks as they learned.

Qualitative data on the course were collected through reflections by students and the module instructors during and at the end of the module. The data were analysed to provide insight on the successes and weaknesses of this applied teaching method on student entrepreneurial development, but also to identify areas where student and instructor observations differed, as to identify areas of focus for further iterations of such experiential learning methods. The focus on a HND programme, where students were ultimately working towards admission into the university's undergraduate programme, addresses an area that warrants research as university education evolves to reach students who may have previously not had the opportunity to study. 


\section{Active and experiential learning in HND programmes}

The UK Higher National Diploma is a vocational degree programme that is often equated to an American Associates Degree or an Australian Advanced Diploma (Wilkins 2001). It is utilized by many UK universities (including the institution where the research was carried out) as an alternate route of entry for undergraduate degree-seeking students who were not accepted under the traditional admission system. As the UK has placed more focus on creating a 'knowledge society' focused on fostering human capital development, so too has the pressure increased to expand higher education to more individuals (Creasy 2013). Students can complete the university's HND programme and then apply some of the credits earned to further study at the university at an undergraduate level. The programme is also designed to enable those who do not continue toward undergraduate education to enter their respective area of employment.

While research has documented the benefits of active and experiential learning environments to student learning (Piercy 2013), little research has focused on the impact of these learning environments on learners enrolled in HND programmes, particularly for students who intend on continuing towards a Bachelor's degree (all but one student included in this research continued onto an undergraduate programme). As universities include HND programmes into their repertoire of teaching, it is important for university educators to understand the unique needs of HND students. This research examines the success and challenges of utilizing an active learning environment for HND student studying entrepreneurialism.

\section{Module layout}

The overall goals of the module were to increase student learning of entrepreneurialism and develop their entrepreneurial skills. Learning outcomes sought by the module included the understanding and application of market research on the development of a new venture, understanding the steps to develop and present a business plan, and understanding and demonstrating the steps required to create, enact, and manage a new business. 
The module was centred on two applied group activities wherein students developed their own enterprises. The first activity was to design and run a pop-up shop in a local shopping centre. The second activity was to compose a business plan for, organize, and host a themed event night at a university venue. The settings for each activity had been planned prior to the start of the module by the instructors by reaching out to external stakeholders, who agreed to provide use of their property.

Each activity was followed by time for reflection and evaluation, allowing for feedback and communication between students and instructors, following the principle that 'engagement in classroom affairs is a two way process' (Slimani-Rolls and Kiely 2014, p. 433). In addition, Cannady and Gallo (2016) found that students who had engaged in reflection reported that it had aided their learning. Following the first activity, students shared their reflections with classmates in a group presentation. The second activity's reflection was captured in a critical essay.

Working within groups served to enhance learning and critical thinking skills (Clinebell and Stecher 2003), build skills transferable to the workplace (Ferrante, Green and Forster 2006; Fearon, McLaughlin and Eng 2012), and increase perceived individual accountability (Ormrod 2008). Teamwork skills are increasingly in demand by employers (Peterson 2012), and can help students share their strengths and develop problem-solving, leadership, and negotiating (Hodkinson-Williams, Stay and Sieborger 2008; Clinebell and Stecher 2003; Fearon, McLaughlin and Eng 2012). In addition, the planned activities involved engagement with external enterprises, both within and outside the university, and working within groups helped ensure the resources available could be shared by everyone.

The applied activities gave students a relatively low-risk environment within which they could encounter and learn from failure, a common occurrence in the entrepreneurial process. Encountering failure during the entrepreneurial process has been argued to enable a new cognitive learning pathway and increase preparedness for future entrepreneurial activities 
(Cope 2011) by creating an essential prerequisite for learning (Sitkin 1992). Sitkin (1996) maintains that experiencing small failures builds up resilience to take on future challenges. However, the cognitive pathway from failure to learning is not foregone nor direct, as emotions and affective factors stemming from stress, embarrassment, and financial loss can hamper one's ability to learn and grow from the failure (Cope 2011; Shepherd 2004).

Pedagogic approaches may be able to prepare students to fail in entrepreneurial tasks such that they are better able to harness the learning opportunities rather than being overwhelmed by the emotional aspects (e.g. Honig 2004). The effectiveness of these approaches is argued to be greatest when the failures are modest in scale and consequence, when they are the result of planning for an uncertain outcome, and when they take place in an environment that is familiar to the individuals (Sitkin 1992). The resulting disequilibrium from these manageable setbacks is argued to motivate students, in a comfortable and safe setting, to learn and apply new notion to avoid repeated failure going forward, based on Piaget's (1950) intellectual equilibrium (Honig 2004).

Each week, the instructor presented the topics and learning goals and discussed how they applied to the group activity. Table 1 shows the module topics and how they applied to the development of the respective group activity. After the lecture, students spent time in small groups applying the day's lesson to the activity. The information was thus presented in a manner that allowed time to discuss and apply the lecture content. Guidance was available from the instructor as needed, and students were given chances to share findings within their groups with the entire class. As the semester progressed, students were given greater autonomy to make decisions. The rationale behind increased autonomy was to engage them in goal-directed, intentional skill and understanding development. Through this 'scaffolded learning' approach, students are initially given support to understand how to undertake a new task. This support is slowly reduced with time to give students a chance to solve the problems on their own and develop cognitive skills in these areas; this strategy has been used successfully 
in business school settings to introduce students to new concepts (Athanassiou, McNett and Harvey 2003; Cowen, Blair and Tailor 2011).

Table 1: Course Sessions and Associated Practical Goals/Outcomes

\begin{tabular}{|c|c|c|}
\hline Session & $\begin{array}{l}\text { Application to Experiential } \\
\text { Learning Activity }\end{array}$ & Skills Developed \\
\hline Course Introduction & $\begin{array}{l}\text { Get the students comfortable } \\
\text { with one another }\end{array}$ & Teamwork, Self-esteem \\
\hline $\begin{array}{l}\text { Sales Generation \& Management in } \\
\text { small and medium enterprises (SMEs) }\end{array}$ & $\begin{array}{l}\text { Pop up shop discussions \& } \\
\text { objective setting }\end{array}$ & $\begin{array}{l}\text { Teamwork, Innovation, } \\
\text { Proactiveness }\end{array}$ \\
\hline Service Design & Pop up shop final preparation & $\begin{array}{l}\text { Teamwork, } \\
\text { Proactiveness, Comfort } \\
\text { with uncertainty }\end{array}$ \\
\hline \multicolumn{2}{|c|}{ Pop up shop } & $\begin{array}{l}\text { Teamwork, } \\
\text { Proactiveness, Self- } \\
\text { esteem }\end{array}$ \\
\hline Presentation Skills & $\begin{array}{l}\text { Presentation planning and } \\
\text { preparation }\end{array}$ & $\begin{array}{l}\text { Guided reflection- What } \\
\text { have I learned? }\end{array}$ \\
\hline \multicolumn{2}{|c|}{ Group Presentations (Assessment 1) } & Teamwork, Self-esteem \\
\hline Generating Business Ideas & $\begin{array}{l}\text { Introduction to Event Night \& } \\
\text { idea generation }\end{array}$ & $\begin{array}{l}\text { Teamwork, Innovation, } \\
\text { Proactiveness }\end{array}$ \\
\hline Entrepreneurs\& innovation & $\begin{array}{l}\text { Identification innovation } \\
\text { aspects within Event Night plan }\end{array}$ & $\begin{array}{l}\text { Teamwork, Innovation, } \\
\text { Proactiveness }\end{array}$ \\
\hline Finance for small businesses & $\begin{array}{l}\text { Event Night financial planning } \\
\text { \& forecasting }\end{array}$ & $\begin{array}{l}\text { Teamwork, } \\
\text { Proactiveness, Comfort } \\
\text { with uncertainty }\end{array}$ \\
\hline Market research & $\begin{array}{l}\text { Event Night market research } \\
\text { collection }\end{array}$ & $\begin{array}{l}\text { Teamwork, Innovation, } \\
\text { Proactiveness }\end{array}$ \\
\hline Small business marketing 1 & Event Night marketing planning & $\begin{array}{l}\text { Teamwork, Innovation, } \\
\text { Proactiveness }\end{array}$ \\
\hline Small business marketing 2 & $\begin{array}{l}\text { Event Night marketing } \\
\text { implementation }\end{array}$ & $\begin{array}{l}\text { Teamwork, Innovation, } \\
\text { Proactiveness }\end{array}$ \\
\hline $\begin{array}{l}\text { Small business resources \& } \\
\text { capabilities }\end{array}$ & $\begin{array}{l}\text { Event Night resource \& } \\
\text { capability planning }\end{array}$ & $\begin{array}{l}\text { Teamwork, } \\
\text { Proactiveness, Comfort } \\
\text { with uncertainty }\end{array}$ \\
\hline Writing strong business plans & Development of business plan & $\begin{array}{l}\text { Teamwork, Innovation, } \\
\text { Proactiveness }\end{array}$ \\
\hline \multicolumn{2}{|c|}{ Time plan and prepare for Event Night } & $\begin{array}{l}\text { Teamwork, } \\
\text { Proactiveness, Self- } \\
\text { esteem }\end{array}$ \\
\hline \multicolumn{2}{|c|}{ Running Event Night } & $\begin{array}{l}\text { Teamwork, } \\
\text { Proactiveness, Self- } \\
\text { esteem }\end{array}$ \\
\hline Critical reflection & $\begin{array}{l}\text { Critical reflection on the course } \\
\& \text { skill development }\end{array}$ & $\begin{array}{l}\text { Guided reflection- What } \\
\text { have I learned? }\end{array}$ \\
\hline
\end{tabular}


Students were informed of the module layout at the beginning of the semester, in line with recommendations by Cotterill (2015). To acclimate students with each other and with active learning, the first two sessions included 'impromptu presentations', an active learning approach that can be used to introduce students to a new course (Thompson, Switky and Gilinsky 2012). Students worked together in small groups to construct paper airplanes and complete a jigsaw puzzle. After both activities, students discussed the aspects that had the greatest impact on success and areas for improvement. As such, students were introduced to applied activities, analysis, and one another before diving into enterprise creation.

The high failure rate of new startups was discussed at the beginning of the semester to help students understand that failure is part of the process and provides a valuable learning experience. The format of the class allowed for setbacks and failures to occur in a manner that allowed students to learn from them rather than be overwhelmed. Evaluation was based on reflections and carrying out the activities, rather than on the success of the business.

Students completed three assessments: a group presentation, a written business plan, and a reflective essay. Instructors assessed the group presentation following the pop-up shop, focusing on the level of critical reflection and presentation skills. For the second assessment, the instructor evaluated the business plans submitted for the second applied activity for quality, professionalism, and feasibility.

For the essay, students reflected on the module, focusing on their perception of the module's hands-on experiences, lectures, and guidance and how it helped them understand entrepreneurialism. They also discussed how they felt they had developed as a result of the course. The essays were graded on their level of analysis of the module and themselves and understanding of the business principles put into practice. Reflection in essay form was used because it has been argued that a structured approach to reflection can enhance students' interpretation of the learning experience and can help students make sense of situations (Platzer, Snelling and Blake 1997; Mezirow 1990). 
As students would be completing a reflective analysis of their experience and relating the experience to their own entrepreneurial development, a questionnaire designed to engage students in thinking about their own entrepreneurial attitudes was completed by students at the beginning of the term. The questions were derived from two entrepreneurial orientation questionnaires that measure entrepreneurial attitudes and traits in students without entrepreneurial experience (only one student had entrepreneurial experience) (Bolton and Lane 2012; Florin et al. 2007). The questionnaire takes an attitudinal approach and provides insight on intention to be entrepreneurial by examining existing attitudes and traits: selfconfidence, creativity, comfort with risk/uncertainty, and proactiveness. The students were asked to rate themselves on each of these traits using a five-point Likert scale. The purpose of the questionnaire was not to measure the students' entrepreneurialism, but rather to engage students in thinking about their learning and skill development from the beginning of the term such that their end-of-term reflections would be anchored in these traits, without dictating that the students stick only to these features.

\section{Methodology}

Twenty-nine business students were enrolled for the weekly yearlong entrepreneurship module. Twenty-six of the twenty-nine students were 'traditional' students who had all recently left secondary school. All students were enrolled in the university's business school HND Programme with the goal of moving onward to undergraduate study.

Qualitative data came from student reflections in the assessments, with data points collected during the group presentations, and a thematic analysis of the final reflective assessments. Students were encouraged to use the questionnaire they had completed at the beginning of the term to help guide their essay but were also informed they could focus on other aspects as they felt appropriate. Understanding that the students may struggle with the writing process (Itua et al. 2014), the questionnaire, and classroom discussions on reflective essays, were used to assist students in their writing and make the task less daunting. The data were collated and coded for 
skills and learning acquired during the course, as well as for points on strengths and weaknesses of the module (Braun and Clarke 2006).

These data were supplemented by instructor observations and reflections that were collected within a regularly updated, dedicated blog. The module leader maintained a blog outlining the course, which was aimed at other educators. The blog was updated after each weekly module. The blog entries were formatted such that entries began with a description of the sessions' learning outcomes and session structure. The entries then included reflections on the individual sessions and the instructor's perception of impact on students. The blog's final post was a reflection on the overall experience.

The session leaders' blog entries were treated like researcher-directed diaries for the purpose of the research. They were collated and thematically analysed by another researcher, who was not an instructor on the module, nor directly involved with the module design. The data were coded for areas where instructor observations aligned or conflicted with student data to identify disconnects between student and instructor expectations and observations within the module.

The results of the analysis will be included in the description of the module activities that follows.

\section{Applied activity one: Pop-up shop}

For the first activity, students were asked to organize a pop-up shop in the city's main shopping centre to promote the university. They were organized into groups of four to five, in line with findings citing the benefit of learning in an applied group setting (Bell 2016a) and the benefits of small groups to increase perception of individual accountability, decrease social loafing (Kerr 1983; Davies 2009), and ensure equitable division of responsibilities (Simon and Hamilton 1994). The instructor guided students to engage with the public by describing activities that the university offered to the public, like the joint university/public library and university's sporting 
events. The sessions' lectures focused on the development of entrepreneurial opportunities through emotional involvement, personal communication, and creativity.

The groups were then asked to create a marketing strategy and plan their event, with the instructor available for suggestions. After creating their plans, groups identified the marketing materials and resources they would need for their shop. Students initially struggled with finding ways to engage their customers, rather than simply disseminate information. Instructors reminded students to keep in mind the lecture's emphasis on communication and creativity. Lectures covered service design and how delivering services differed from delivering products, after which students were asked to design a basic service blueprint.

Each group was assigned a two-hour block to set up and run their pop-up shop in the shopping centre. The goal was to expose students to the real-world challenges of developing an enterprise, to apply their learning, and develop entrepreneurial skills. Students used different strategies to attract the public. Some groups offered refreshments, and almost all groups distributed promotional materials with the university logo. One group gave away free tickets to a university-sponsored sporting event. The instructors encouraged frustrated groups to change their approach and provided guidance as needed. For example, the instructors encouraged some groups who were waiting inside the shop for the public to enter to proactively approach the public outside.

\section{Assignment one: Reflection and presentation}

To prepare for their group presentation, students reflected on their successes, how their strategy changed while running their shops, and what they would have done differently. Prior to the presentations, a session was conducted to review elements of successful presentations and public speaking, including visual components, presentation style, and elocution. The session was combined with the business concept of the 'elevator pitch'. Students were asked to consider how their presentation skills would also be applicable to real-world entrepreneurial pitches and proposals, in line with findings by Ames (1992) that students will be more likely to 
fully engage in learning when they perceive a meaningful reason or applicability in the activity. Students also viewed video examples of real entrepreneurial product pitches, both successful and unsuccessful, and asked to analyse them for strengths and weaknesses.

The group presentations revealed that students felt engaged and were excited to present their findings. The ideas for improvement showed that they had begun to think about the learning concepts and included being more proactive to engage with the public and considering their audience when choosing promotional items and decor. The module leaders observed that students were developing their presentation skills and their collective learning skills, but still seemed uncertain about their own entrepreneurial abilities. The initial activity appeared to leave students excited and nervous for the next, more demanding activity.

\section{Applied activity two: Social event}

Students were assigned to organize and carry out a profitable theme-night event for university students at the on-campus university bar. The instructors provided less direction for this activity but were available for specific questions. Students were encouraged to apply the lectures and work as a team to decide how to create, plan, and run the event. To facilitate this activity, the module leader worked closely with the university's Student Union representatives (who have authority over use of the venue) and the university bar manager. It was agreed that the Student Union would set aside consecutive weekly evenings on which the student groups could host their events. This activity saw more interaction between the external stakeholders and the students, who needed to work directly with the bar manager and the Student Union.

In line with findings by Hansen (2006) that students form effective groups when allowed to engage initially with each other and 'interview' potential group members, students were allowed to form their own groups for the activity, based on their experiences working together throughout the first part of the term. The goal was to lessen the anxiety about group dynamics and allow students who trusted one another to focus on the tasks at hand. 
The role of the instructor for this activity was to provide information on relevant business principles, including: generating business ideas, market research, small-business marketing, and finance, and to ensure students were working towards the composition of their business plans for the event. This information was presented both in instructor-led lectures and by guest lecturers from local business owners, providing an opportunity for discussion with field experts. In addition, the external stakeholders were invited to speak to the class and answer specific questions.

\section{Assignment two: Composition and enactment of business plan}

The groups composed a business plan over the course of six weeks detailing the management, marketing, and financing of the theme night, as well as the resources required. These principles were outlined during the lectures, and students then had time during the session to work with their groups and implement or plan for the principle learned that day. Many strategic approaches to the creation of the business plans were covered, and students were encouraged to think outside of traditional approaches to their enterprise (Alstete 2014). The instructors were available during group-work periods and at drop-in sessions to answer questions; however, they encouraged students to work autonomously within their groups to decide the details of their business plans and how to apply their plans to the event night.

As students developed their business plans, the instructors held consultation sessions to ensure understanding and allow for intervention if students were veering off course or felt stuck. The time also allowed instructors to assess understanding of the course material. Instructors observed that while students' understanding had grown with the progression of the module, the students had initially struggled with linking different business plan elements to make a holistic and realistic product. The composition of lists of tangible items for the event and its marketing that would be summarily purchased seemed to ground the project and make it more 'real' for students. This thus became the springboard off of which the groups were able to conceptualize the rest of the business plan. 
The approach to market research was undertaken in a similar way by all groups, who split themselves into primary and secondary data collection teams. The primary data collection teams talked to students about their preferences and to businesses and individuals with experience at hosting events. The secondary data teams focused on online searches for events held at other venues and other universities. While successful at conducting market research, students needed guidance to translate the findings into event and marketing ideas. Instructors encouraged students to be creative and to remember the principles of applied risk that had been covered in a previous session.

Students submitted business plans for assessment and afterwards worked with the instructor to procure the resources outlined in the business plans. Closer to the event date, students met with the external stakeholders outside of class to coordinate the logistics and ensure their event plans were appropriate. One group encountered a setback when their theme was deemed inappropriate by the university leadership and had to be changed (after the group had printed promotional materials). Despite this obstacle, the group adapted and learned a valuable lesson about considering all stakeholders and audiences when planning an enterprise.

Before the events, the groups met separately with the instructor and the venue manager to conduct a final walk-through. Students were able to use this meeting to 'sell' their business plans to the venue manager, who was willing to negotiate on specials and discount vouchers, depending on how successful he believed the event would be for his establishment. Students were thus able to use their business plans and demonstrate the presentation skills covered in the first assessment.

During the final walk-through, the instructors noted that, although the groups had allocated tasks to each member leading up to the event, they lacked strong leadership to manage the many details associated with the event. Event management is often a part of business education programmes (Hadley 2012), but had not been a focus of the module. Groups needed to decide when they would begin to setup, and how they would manage the event itself. The 
instructors had to take on a more assertive role to ensure that the students worked out their last-minute planning.

Groups carried out their events on consecutive Monday nights and offered themed games, food and drink specials, and specialty themed cocktails for purchase. One group had negotiated to have pizza delivered, another to have a nightclub subsidise taxis to take people to the nightclub after the event. A group sent its members onto campus to recruit students already planning on going to a nightclub, promising a fun 'pre-club' event with drink specials and games. The event nights each drew around a 100 students.

\section{Assignment three: Reflective essays}

Overall, the reflective essays indicated that both the module's taught content and the applied activities had a positive impact on the learners' development. The essays highlighted the impact of the applied activity on the development of their knowledge and understanding of entrepreneurialism, as well as their self-confidence, group-work skills, comfort with the uncertainties of starting and running a business, and creativity.

Students reported that they not only understood the entrepreneurial process and the course content as a result of the experience, they also believed they were capable of engaging in entrepreneurial ventures. The increase in understanding and self-confidence was clear throughout most of the essays:

"Before, I did not understand what an entrepreneur was, whereas now after all the teaching sessions I feel much more confident in my knowledge of the business entrepreneur and small businesses."

"(The activities) showed me that I had worthwhile things to offer. I never thought I could have done things like this before." 
Some students cited an appreciation for the role that the lectures played in preparing students for the events and aiding their confidence:

"The lecture prior to the pop up shop gave us a lot of information and learning about how to speak well to a group of people and how to present properly."

Students also highlighted the impact of working within groups on their learning. Many students remarked that working on the applied activities in groups made them feel more confident, as they appreciated feeling 'heard' and 'respected' by their classmates. They also reported that working with a team made them feel more responsible for their contribution to the assignments:

"I am more confident and have a clearer understanding of the successes and pitfalls of an entrepreneurial project and the importance of effective team work and good communication in order to make it happen."

"The (group activities) allowed me to be a worthy contributor to the success of our group."

While overall response to the collective learning format was positive, students aired grievances (often cited by the literature) about social loafing/freeloading, discomfort with expressing opinion in front of their group, and a desire to be assessed individually.

Students reflected on the way the applied learning activities removed them from their comfort zones and gave them an avenue to be creative. They also highlighted that the lectures on innovation helped them understand the many sources of business ideas (i.e. life experience and hobbies):

"Being innovative and thinking of an idea was something I had never really had much experience with before, but I realized how essential it is to improve situations." 
Furthermore, students expressed that their comfort had increased with respect to the uncertainty behind implementing their creative ideas and making business decisions. The concept of calculating risk in order to mitigate uncertainty was mentioned often and was presented as a new and influential concept. The presence of teammates with whom they could consult was reported to have helped students be more comfortable with uncertainty:

"I always thought risk was a bad thing. I'm now much more open to take risks as long as I have some base of information."

\section{Discussion}

The essays, along with the discussions with students throughout the semester and the instructors' observations, indicated that the students were receptive to the module's format. Students had initially expressed alarm with the course format and were hesitant to engage, anxiety stemming from the non-traditional format and the essay requirement, but by the end of the term, students had learned the module content, but also had improved their belief in their abilities and the value of their contributions.

Students expressed overall satisfaction with their performance as part of a group, both in the reflections and in their student satisfaction surveys. While the increase in confidence was apparent from the reflections and students' actions during the module, the instructors found that students at times became overconfident. Instructors had to intervene when groups were close to implementing their event night enterprises at the expense of attention to detail. Students had allocated activities in the lead-up to the event; however, they had not taken into account all the details necessary to carry out their plans and needed extra help at the final stage of both activities. For example, students did not consider where electrical outlets were located in the event room and thus had to alter their plans of where to place equipment.

This apparent 'overconfidence' may be line with theories of self-efficacy in entrepreneurship. While students referred to 'confidence' and 'self-esteem', the way they described this 
confidence in relation to their ability to carry out the business start-up process aligns with selfefficacy, which is the conscious belief in one's ability to complete an activity or task, rather in one's overall self-worth. It may be aligned with an internal locus of control, that is, the belief that students are responsible for their own success or failure. Forbes (2005) found that individuals are more drawn to tasks at which they have higher self-efficacy, which provides a linkage between increased self-efficacy in the entrepreneurial process and a greater degree of entrepreneurialism in an individual. Piperopoulos and Dimov (2015) found that students' higher self-efficacy is associated with a higher entrepreneurial intention following an experiential classroom setting.

The improvements in students' group work skills, confidence/self-efficacy, creativity, and comfort with uncertainties indicate that students developed skills that both are entrepreneurial and may have a positive impact on their employability. The literature (Peterson 2012; Hodkinson-Williams et al. 2008) has argued that effective group-work skills gained during education can translate in to job skills. Kivinen, Nurmi and Salminiitty (2000) and Bell (2016b) highlighted that employability may be improved by possessing entrepreneurial traits.

The inevitable setbacks and small-scale failures encountered by the teams provided an avenue to learning and overcoming obstacles, in line with suggestions by Honig (2004) that simulations or other experiential approaches may prepare students to learn from failure rather than be overwhelmed. This study's approach was more directed than that suggested by Honig, exposing students to a real business experience, but keeping it within a familiar environment (the university campus and surrounding area), with activities planned in advance, and without extreme consequences for failure (grades were not based on profitability) (Sitkin 1992). As a result, students who were disappointed by setbacks were able to feel as though they developed as a result and were able to harness the experiences in a manner that made them more comfortable with future risks, which ostensibly means with the possibility of failure. The overriding belief in their own abilities also lends support to the finding that students learned from their setbacks and failures. 
In common with all group-work situations, some students contributed more than others. Social loafing or freeloading is a well-known and well-reviewed issue in the literature (Dommeyer 2007; Harkins and Jackson 1985). Some students initially encountered difficulty communicating effectively within their groups and some preferred communicating electronically. Chapman and van Auken (2001) maintain that many group issues are caused by students' lack of understanding of how to manage and work within a group. Possible solutions in future iterations may be to assign students into their groups (Hansen 2006), to spend time during the lecture period discussing group-work skills, and to have students compose binding group agreements with division of tasks.

From instructor observations and from the tone of the language used when speaking about other group members, the instructors felt that working in a group gave students a way out of responsibility when something went wrong; they could simply say the group was ineffective and the student should be assessed individually. While it appeared that students' self-efficacy and internal locus of control had been increased, it also appeared that students had not fully reconciled this with the reality that all entrepreneurial ventures require interactions with others, and that the ability to undertake future ventures will require successfully navigating these relationships. The concept of effective team roles and integration to accomplish a common goal seemed to still be beyond the students in the short time period allowed for the assignment.

One theme that emerged in reflections and student feedback was the preference for individual (rather than group) assessment and a desire for more individual assignments. The reflective essays were assessed individually; however, since the course's active learning format required students to learn how to work with many stakeholders and to understand the process of planning and launching an entrepreneurial enterprise, there was value in having students work and be assessed as part of a group. 
Lastly, the overall improvements in the depth and analysis included in the second set of reflections indicated that students improved their ability to analyse and reflect on situations, argued by Lave and Wenger (1991) and Fejes (2011) to lead to students' holistic development. Students interpreted their experience, taking part in a structured approach to reflection, in line with findings by Mezirow (1990). The improvement in the ability to critically reflect will help students as they continue on their path towards an undergraduate degree.

\section{Conclusion}

Despite students' initial uncertainty about the module structure, HND students thrived when given applied activities, resources, and guidance. The students' critical reflections and module evaluations showed that they had come to understand and appreciate the format of the module as the term progressed. Students learned the module concepts, gained real-world experience, developed their ability to critically reflect and benefited from working with multiple stakeholders. They left the module with a greater understanding not only of the entrepreneurial process, but also how the lessons applied to the enactment of a venture. There were limitations in how effective the module could be in affecting change in students; the group work dynamic was not wholly embraced by all students and was often seen as a way to shirk responsibility.

This research shows the benefits and challenges of using an experiential learning environment to teach entrepreneurialism to HND students. Previous research has argued in favour of including work experience in education during HND programmes (e.g. Lowe and Gayle 2016) in order to prepare students for the workplace. This study included real-life enterprise opportunities and activities in the HND education process in order to prepare for further study. The applied learning environment was paired with lecture-based information transfer, giving students an experiential approach, offering guidance, and easing students into the expectations of a business undergraduate course of study. In addition, the module included activities aimed at improving students' writing, analysis, and cognition, key skills for transition into a Bachelor's 
degree programme. Further research in this area will serve to refine the learning and teaching methods that best prepare HND students for their next step towards a bachelor's degree. 


\section{References}

Alstete, J. W. 2014. "Strategy Choices of Potential Entrepreneurs." Journal of Education for Business 89(2): 77-83.

Ajzen, I. 1985. "From Intentions to Actions: A Theory of Planned Behaviour." Chapter 2 in Action Control. Heidelberg: Springer-Verlag.

Ames, C. 1992. "Classrooms: Goals, Structures, and Student Motivation." Journal of Educational Psychology 84: 261-271.

Athanassiou, N., J.M. McNett, and Harvey, C. 2003. "Critical Thinking in the Management Classroom: Bloom's Taxonomy as a Learning Tool." Journal of Management Education 27(5): 533-555.

Arvanites, D. A., J.M. Glasgow, J.W. Klingler, and S.A. Stumpf. 2006. "Innovation in Entrepreneurship Education." Journal of Entrepreneurship Education 9: 29-44.

Bell, R. 2016a. "The Continuing Search to Find a More Effective and Less Intimidating Way to Teach Research Methods in Higher Education." Innovations in Education and Teaching International 53(3): 285-295.

Bell, R. 2016b. "Unpacking the Link between Entrepreneurialism and Employability: An Assessment of the Relationship between Entrepreneurial Attitudes and Likelihood of Graduate Employment in a Professional Field." Education + Training 58(1): 1-18.

Bevan, D. and C. Kipka. 2012. "Experiential Learning and Management Education." Journal of Management Development 31(3): 193-197.

Bolton, D.L., and M. Lane. 2012. "Individual Entrepreneurial Orientation: Development of a Measurement Instrument." Education + Training 54(2/3): 219-233.

Braun, V., and V. Clarke. 2006. "Qualitative Research in Psychology." Journal of Psychology 3(2): 77-101.

Cannady, R. E., and K. Z. Gallo. 2016. "Write Now! Using Reflective Writing Beyond the Humanities and Social Sciences." Journal of Further and Higher Education 40(2): 188-206.

Chang, J., A. Benamraoui, and A. Rieple. 2014. "Learning-by-doing as an Approach to Teaching Social Entrepreneurship." Innovations in Education and Teaching International, 51(5): 459-471.

Chapman, K. J. and S. van Auken. 2001. "Creating Positive Group Project Experiences: An Examination of the Role of the Instructor on Students' Perceptions of Group Projects." Journal of Marketing Education 23(2): 117-127. 
Clinebell, S. and M. Stecher. 2003. "Teaching Teams to be Teams: An Exercise Using the MyersBriggs ${ }^{\circledR}$ Type Indicator and the Five-Factor Personality Traits." Journal of Management Education 27: 362-383.

Cope, J. 2011. "Entrepreneurial Learning from Failure: An Interpretative Phenomenological Analysis." Journal of Business Venturing 26(6): 604-623.

Cornell, R. M., C.B. Johnson, and C.W. Schwartz. 2013. "Enhancing Student Experiential Learning with Structured Interviews." Journal of Education for Business 88(3): 136-146.

Cotterill, S. T. 2015. "Tearing up the Page: Re-thinking the Development of Effective Learning Environments in Higher Education." Innovations in Education and Teaching International 52(4): 403-413.

Cowen, J., W. Blair, and S. Taylor. 2011. "The Use of Scaffolding in the Financial Planning Classroom: An Australian Case Study". Australasian Accounting Business \& Finance Journal 5(3): 3-16.

Creasy, R. 2013. "HE lite: Exploring the Problematic Position of HE in FECs." Journal of Further and Higher Education 37(1): 38-53.

Davis D., M. Morris, and J. Allen. 1991. "Perceived Environmental Turbulence and Its Effect on Selected Entrepreneurship, Marketing, and Organizational Characteristics in Industrial Firms." Journal of the Academy of Marketing Science 19(1): 43-51.

Davies, W.M. 2009. "Groupwork as a Form of Assessment: Common Problems and Recommended Solutions." Higher Education 58: 563-584.

Dommeyer, C.J. 2007. "Using the Diary Method to Deal with Social Loafers on the Group Project: Its Effects on Peer Evaluations, Group Behavior, and Attitudes." Journal of Marketing Education 29(2): 175-188.

Duval-Couetil, N., C.M. Gotch, and S. Yi. 2014. "The Characteristics and Motivations of Contemporary Entrepreneurship Students." Journal of Education for Business 89(8): 441-449.

Fayolle, A., and B. Gailly, B. 2015. "The impact of entrepreneurship education on entrepreneurial attitudes and intention: Hysteresis and persistence." Journal of Small Business Management 53(1): 75-93.

Fearon, C., H. McLaughlin, and T.Y. Eng. 2012. "Using Student Group Work in Higher Education to Emulate Professional Communities of Practice." Education + Training, 54(2/3): 114-125.

Forbes, D. P. 2005. “Are Some Entrepreneurs More Overconfident than Others?" Journal of Business Venturing 20(5): 623-640.

Fejes, A. 2011. "Confession, In-Service Training and Reflective Practices." British Educational Research Journal 37(5): 797-812. 
Ferrante, C. J., S.G. Green, and W.R. Forster. 2006. "Getting More out of Team Projects: Incentivizing Leadership to Enhance Performance." Journal of Management Education 30(6): 788-797.

Florin J., R. Karri, and N. Rossiter. 2007 "Fostering Entrepreneurial Drive in Business Education: An Attitudinal Approach." Journal of Management Education 31(1): 17-42.

Gibb, A. 2002. "In Pursuit of a New "Enterprise" and "Entrepreneurship" Paradigm for Learning: Creative Destruction, New Values, New Ways of Doing Things and New Combinations of Knowledge." International Journal of Management Reviews 4(3): 233-269.

Gird, A. and J.J. Bagraim. 2008. "The Theory of Planned Behaviour as Predictor of Entrepreneurial Intent amongst Final-Year University Students." South African Journal of Psychology, 38 (4): 711-724.

Hadley, B. 2012. "Using Information Communication Technologies to Develop Dynamic Curriculum Frameworks for Diverse Cohorts: A Case Study from Event Management." Journal of Further and Higher Education 36(2): 263-290.

Hansen, R. S. 2006, "Benefits and Problems with Student Teams: Suggestions for Improving Team Projects." Journal of Education for Business 82(1): 11-19.

Harkins, S. G. and J.M. Jackson. .1985. "The Role of Evaluation in Eliminating Social Loafing." Personality and Social Psychology Bulletin 11: 457-465.

Hodkinson-Williams, C., H. Stay, and I. Sieborger. 2008. "Developing Communities of Practice within and Outside Higher Education Institutions." British Journal of Educational Technology, 39(3): 433-42.

Honig, B., 2004. "Entrepreneurship Education: Toward a Model of Contingency-Based Business Planning." Academy of Management Learning \& Education 3(3): 258-273.

Hynes, B. and I. Richardson. 2007. "Entrepreneurship Education: A Mechanism for Engaging and Exchanging with The Small Business Sector." Education + Training 49(8/9): 732-744.

Itua, I., M.Coffey, D. Merryweather, L. Norton, and A. Foxcroft. 2014. "Exploring Barriers and Solutions to Academic Writing: Perspectives from Students, Higher Education and Further Education Tutors." Journal of Further and Higher Education 38(3): 305-26.

Jack, S. L. and A.R. Anderson. 1999. "Entrepreneurship Education within the Enterprise Culture: Producing Reflective Practitioners." International Journal of Entrepreneurial Behaviour and Research, 5(3): 110-125.

Jones, B. and N. Iredale. 2010. "Enterprise Education as Pedagogy." Education + Training 52(1): 7-19. 
Jones, C. and J. English. 2004. "A Contemporary Approach to Entrepreneurship Education", Education + Training 46(8/9): 416-423.

Kerr, N. L. 1983. "Motivation Losses in Small Groups: A Social Dilemma Analysis." Journal of Personality and Social Psychology 45: 819-828.

Kivinen, O., Nurmi, J. and Salminiitty, R. (2000), "Higher Education and Graduate Employment in Finland", European Journal of Education 35(2), pp. 165-177.

Kolb, D. 1984. Experiential Learning. Englewood Cliffs: Prentice Hall.

Lave, J. and E. Wenger. 1991. Situated Learning: Legitimate Peripheral Participation. Cambridge: Cambridge University Press,.

Lowe, J. and V. Gayle. 2016. "From Lifelong Learning to Youth Employment: Back to the Future for Higher Education in Scotland's Colleges." Journal of Further and Higher Education 40(3): 351-371.

McClelland, D.C., J.W. Atkinson, R.A. Clark, and L. Lowell. 1953. The Achievement Motive. New York: Appleton-Century-Crofts.

Mezirow, J. 1990. Fostering Critical Reflection in Adulthood. San Francisco: Jossey-Bass.

Niehm, L., M. Fiore, M. Jeong, and J. Kim. 2007. “Pop-up Retail's Acceptability as an Innovative Business Strategy and Enhancer of the Consumer Shopping Experience." Journal of Shopping Center Research 13(2): 1-30.

Ormrod, J. E. 2008. Human Learning. Upper Saddle River: Pearson.

Peterson, C. 2012. "Building the Emotional Intelligence and Effective Functioning of Student Work Groups: Evaluation of an Instructional Programme." Journal of Marketing Education 25(1): 37-45.

Piaget, J. 1950. The Psychology of Intelligence. London: Routledge and Kegan.

Piercy, N. 2013. "Evaluating Experiential Learning in the Business Context: Contributions to Group-Based and Cross-Functional Working." Innovations in Education and Teaching International 50(2): 202-213.

Piperopoulos, P. and D. Dimov. 2015. "Burst Bubbles or Build Steam? Entrepreneurship Education, Entrepreneurial Self-Efficacy, and Entrepreneurial Intentions." Journal of Small Business Management 53(4): 970-985.

Platzer, H., J. Snelling, and D. Blake. 1997. "Promoting Reflective Practitioners in Nursing: A Review of Theoretical Models and Research into the Use of Diaries and Journals to Facilitate Reflection." Teaching in Higher Education 2(2): 103-121. 
Reid, M., S. Brown, and K. Tabibzadeh. 2012. "Capstone Teaching Models: Combining Simulation, Analytical Intuitive Learning Processes, History and Effectiveness." Journal of Education for Business 87(3): 178-184.

Shepherd, D.A. 2004. "Educating Entrepreneurship Students about Emotion and Learning from Failure." Academy of Management Learning \& Education. 3(3): 274-287.

Sherman, P.S., T. Sebora, and L.A. Digman. 2008. "Experiential Entrepreneurship in the Classroom: Effects of Teaching Methods on Entrepreneurial Career Choice Intentions." Journal of Entrepreneurship Education 11: 29-42.

Simon, B. and D.L. Hamilton. 1994. "Self-stereotyping and Social Context: The Effects of Relative In-group Size and In-group Status." Journal of Personality and Social Psychology 66: 699-711.

Sitkin, S.B., 1992. "Learning Through Failure: The Strategy of Small Losses." Research in Organizational Behavior 14: 231-266.

Sitkin, S. 1996. "Learning through Failure: The Strategy of Small Losses." In Organizational Learning, edited by M. Cohen and L. Sproull, 541-577. Thousand Oaks, CA: Sage.

Slimani-Rolls, A. and R. Kiely. 2014. "We are the Change that We Seek": Developing Teachers' Understanding of their Classroom Practice." Innovations in Education and Teaching International 51(4): 425-435.

Smith, A.J., L.A. Collins, and P.D. Hannon, 2006. "Embedding New Entrepreneurship Programmes in UK Higher Education Institutions: Challenges and Considerations." Education + Training 48 (8/9): 555-567.

Solomon, G. 2008. "Entrepreneurship Education in the United States." Entrepreneurship and Higher Education, edited by J. Potter, 95-118. OECD and LEED, Paris.

Thompson, K. J., B. Switky, and A. Gilinsky. 2012. "Impromptu Presentations: Boosting Student Learning and Engagement through Spontaneous Collaboration." Journal of Education for Business 87(1): 14-21.

Van Gelderen, M., M. Brand, M. van Praag, W. Bodewes, E. Poutsma, and A. Van Gils. 2008. "Explaining Entrepreneurial Intentions by Means of the Theory of Planned Behaviour." Career Development International 13(6): 538-559.

Wilkins, S. 2001, "An Analytical Model to Assess the Efficacy of the British HND Programme in the Arabian Gulf Region." Assessment and Evaluation in Higher Education 26(6): 579-591.

Zahra, S. A. and F. Welter. 2008. "Entrepreneurship Education for Central, Eastern and Southeastern Europe." In Entrepreneurship and Higher Education, edited by J. Potter, 165-192. OECD and LEED, Paris. 